\title{
Comparative observations on Cephaleuros parasiticus and C. virescens (Trentepohliaceae, Chlorophyta) from India
}

\author{
Yasuo Suto ${ }^{1}$, E. K. Ganesan ${ }^{2, a, *}$ and John A. West ${ }^{3}$ \\ 15-11-46, Agenogi, Matsue, Shimane, Japan \\ ${ }^{2}$ Instituto Oceanográfico, Universidad de Oriente, Cumaná 6101, Venezuela \\ ${ }^{3}$ School of Botany, University of Melbourne, Parkville, VIC 3010, Australia
}

Cephaleuros parasiticus and C. virescens were collected from Kerala and Tamil Nadu, India. Macroscopic and microscopic features were observed and their comparative features were discussed. The lesions of $C$. parasiticus occur on the upper and lower leaf surfaces although zoosporangia form only on the lower surface. The thalli grow subepidermally and intramatrically, causing necrosis of whole leaf tissue. On the other hand C. virescens thalli develop on the upper surface and zoosporangia form on the upper surface, the thalli grow subcuticularly, and only the host epidermal and palisade cells are necrosed. Syzygium aromaticum and Polyalthia longifolia are new host plants of C. parasiticus and C. virescens, respectively.

Key Words: Cephaleuros parasiticus; C. virescens; comparative observations; host plants; Polyalthia; Syzygium

\section{INTRODUCTOIN}

Cephaleuros grows on living leaves, and other parts, of woody plants mainly in the tropics and the subtropics. Three species of Cephaleuros have been reported in India; C. parasiticus Karsten on Camellia sinensis (L.) O. Kuntze in tea plantations (Petch 1923, Ponmurugan et al. 2010, Ramya et al. 2013), C. solutus Karsten on Pyrus sp. in Varanasi (Chowdary and Jose 1979) and C. virescens Kunze on various host plants from various districts (Cunningham 1897, Mann and Hutchinson 1904, Saxena 1961, Panikkar et al. 1989, Gokhale and Shaikh 2012).

Although C. virescens has been reported as the pathogen of various plants, Printz (1939) indicated that it is probably comprised of several species. It is important to identify correctly these species for diagnose the algal disease. We had a chance to collect $C$. parasiticus and $C$. virescens at the same time and observed macroscopic and microscopic morphology, and their comparative features of them.

\section{MATERIALS AND METHODS}

Four samples were collected as follows:

Cephaleuros parasiticus, host: Syzygium aromaticum Merr. et Perry (Clove tree); locality: Hadar Park, Munnar, Kerala, India; collection: Sep 26, 2013, by Ganesan, E. K. (YSH-3010).

C. virescens, host: Polyalthia longifolia (Sonn.) Thw. (Mast tree or Cemetery tree); locality: Chennai, Tamiladu, India; collections: Sep 5, Nov 7, and Dec 13, 2013, by Ganesan, E. K. (YSH-3011, 3012, and 3013).

Specimens used in this study are deposited in the pri-
(9) $\$$ This is an Open Access article distributed under the terms of the Creative Commons Attribution Non-Commercial License (http://creativecommons.org/licenses/by-nc/3.0/) which permits unrestricted non-commercial use, distribution, and reproduction in any medium, provided the original work is properly cited.
Received February 21, 2014, Accepted May 26, 2014

* Corresponding Author

E-mail: ekganesan@gmail.com

Tel: +91-044-42695151, Fax: +91-044-27107101

${ }^{a}$ Present address: 3-A, Srinivas Terrace, 52, II Main Road, Gandhi Nagar, Adyar, Chennai, Tamil Nadu 600 020, India 
vate herbarium of Yasuo Suto (herb. YSH).

Macroscopic features of lesions and algal thalli were observed under a hand-lens and a stereoscopic microscope. Several pieces were peeled from the leaf surface and sections were made by hand with a razor blade. Sections were placed in a drop of Shear's fluid ( $1 \mathrm{~g}$ of potassium acetate, $30 \mathrm{~mL}$ ethanol, $20 \mathrm{~mL}$ of glycerin, and 50 $\mathrm{mL}$ of distilled water) on a glass slide with a cover glass sealed to observe under a light microscope. Microscopic features of thalli, filaments, and reproductive organs were observed. Dimensions of filamentous cells, gametangia, and zoosporangia were measured ( $\mathrm{n}=20$ or 30 ) and the ranges of the value were noted.

\section{OBSERVATIONS}

\section{Cephaleuros parasiticus Karsten}

Lesions are more or less circular spots, 1-5 mm in diameter, dark red brown with a purple stained margin. Lesions develop into the leaf tissue from the upper surface to the lower surface and each spot is visible on both the surfaces (Fig. 1A \& B). Tufts of sporangiophores with zoosporangia are produced on the lower surface of the lesion (Fig. 1C).

Thalli grow subepidermally on the upper and lower leaf surfaces and intramatrically. The filamentous cells invade the cuticle and occasionally make a small mass, but do not expand subcuticularly. They develop vertically beneath epidermal cells and invade into intercellular space of cells of the palisade and spongy tissues (Fig. $1 D-G)$. No setae project on the lesions. A few immature gametangia are formed subcuticularly (Fig. 1H). Sporangiophores project mainly from the lower leaf surface and rarely from the upper leaf surface, being cylindrical, erect, 300-640 $\mu \mathrm{m}$ long and 13-19 $\mu \mathrm{m}$ wide, 4 to 8 cells, in tufts of 2 to 5 . Head cells are borne terminally on the sporangiophores and produced mostly 4 or 6 sporangiate-laterals, zoosporangia and their suffultory cells. Zoosporangia are elliptical, 21.5-29 $\mu \mathrm{m}$ long and 17-21.5 $\mu \mathrm{m}$ wide, yellow to orange (Fig. 1I).

The cells of the whole leaf tissues, including the epidermis, palisade tissue, spongy tissue, and vascular bundles become necrotic, turning brown to dark brown (Fig. 1D$\mathrm{H})$.

\section{Cephaleuros virescens Kunze}

Thalli form more or less circular raised disks with cre- nate margins, 1-7 mm (mostly 3-4 mm) in diameter, 15-50 $\mu \mathrm{m}$ in height, olive in color (Fig. 2A-C). No thalli grow on the lower leaf surface. On young leaves, a circular purple stain occurs around the thallus on the upper surface and also the opposite lower surface (Fig. 2A). On old leaves, although no stain occurs around the thallus, a circular yellow stain occurs on the opposite lower leaf surface. Green black granules of gametangia aggregate at the marginal portion of thallus (Fig. 2D). Tufts of sporangiophores with zoosporangia are produced on the thallus (Fig. 2E).

Thalli grow subcuticularly on the upper leaf surface (Fig. 2F \& G). Disks of thalli are composed of pseudoparenchymatous ramuli with no gaps. Filamentous cells are long-cylindrical, 29-48 $\mu \mathrm{m}$ long and 10-16 $\mu \mathrm{m}$ wide with a length / width ratio of 2.4-3.6, branching by equal dichotomy (Fig. 2H). Setae rarely develop as slender filaments of 3 to 6 cells, pale yellow solitary. Gametangia are produced beneath the cuticle, enlarging in an elliptical shape, 26$36 \mu \mathrm{m}$ long and 17-22 $\mu \mathrm{m}$ wide, yellow to orange, solitary or in clusters (Fig. 2I). Sporangiophores project from the thallus of the upper leaf surface, being cylindrical, erect, 110-310 $\mu \mathrm{m}$ long and 14-19 $\mu \mathrm{m}$ wide, 3 to 5 cells, solitary or in tufts of 2 to 5 . Head cells are borne terminally on the sporangiophores and produce 4 to 8 sporangiate-laterals, zoosporangia and their suffultory cells. Zoosporangia are elliptical, 22-25 $\mu \mathrm{m}$ long and 19-23 $\mu \mathrm{m}$ wide, yellow to orange (Fig. 2J).

Epidermal and palisade cells of the leaf become necrotic, turning brown and red-brown beneath the thallus (Fig. 2F).

\section{DISCUSSION}

The morphological characteristics of the samples largely agreed with the description by Thompson and Wujek (1997) and Suto and Ohtani (2009). In our collection, mature gametangia were not observed in C. parasiticus. Setae were never or rarely observed in C. parasiticus and C. virescens, respectively. The size of zoosporangia is the same for both two species, although the zoosporangia of C. parasiticus were reported to be smaller than those of C. virescens (Thompson and Wujek 1997). These aspects are considered to be influenced by host plants, collecting seasons, and environmental conditions. The stain around and the opposite portion of lesions and thalli might be caused by anthocyanin produced by host tissue (Thompson and Wujek 1997). The occurrence of the stain differed with the leaf age in C. virescens on P. longifolia.

Macroscopic features of the spots on the leaves are 

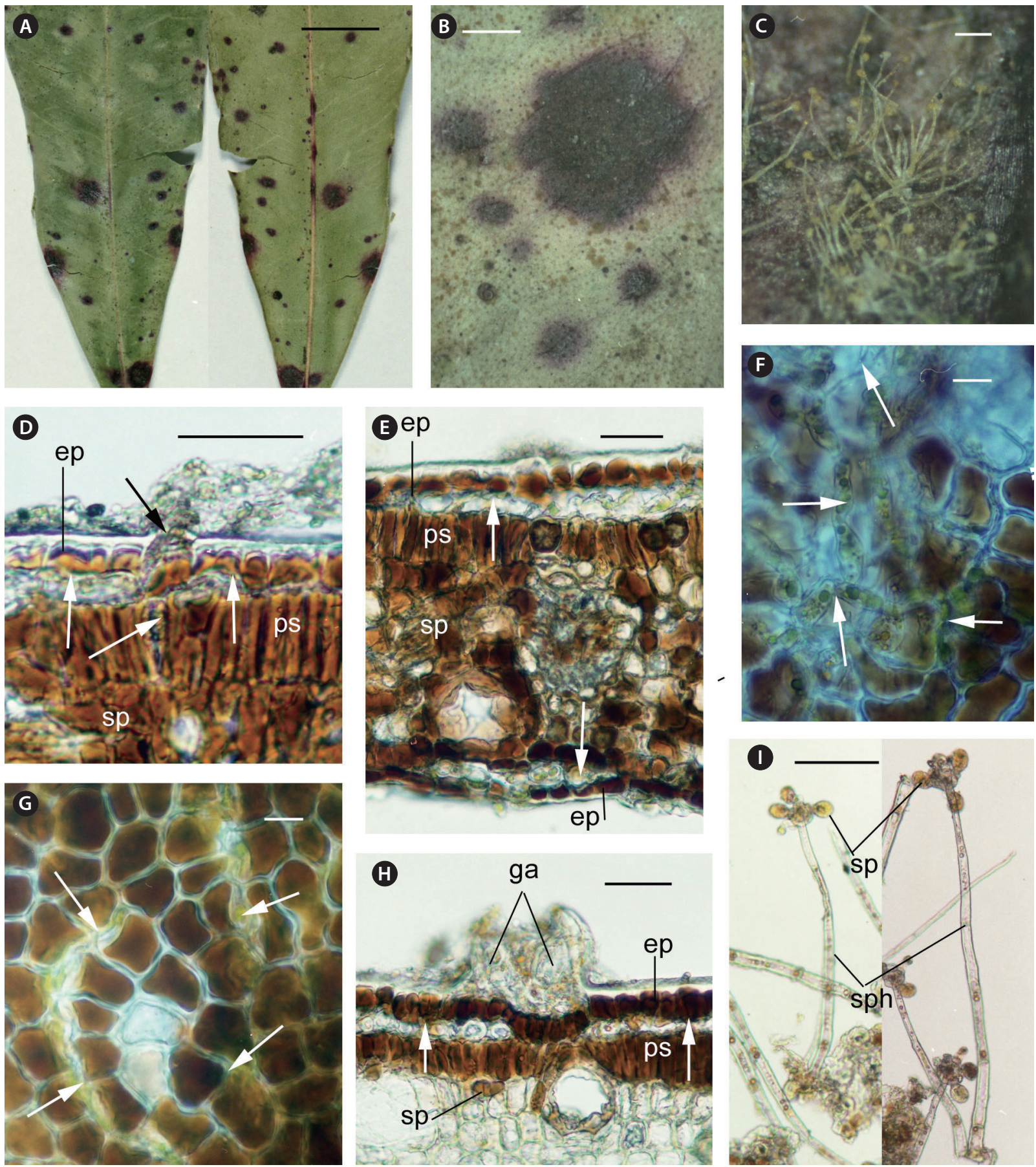

Fig. 1. Cephaleuros parasiticus in Syzygium aromaticum. (A) Lesions on leaf surface (left, upper surface; right, lower surface). Notice lesions on both surfaces. (B) Enlarged view of lesions with purple stain on upper surface. (C) Tufts of sporangiophores with zoosporangia forming on lower leaf surface of lesion. (D) Transverse section of lesion showing invasion of filaments (arrows) into tissue of leaf. Necrosis of epidermal cells (ep), palisade cells (ps), and spongy cells (sp). (E) Transverse section of lesion showing development of subepidermal thallus (arrows) of both leaf surfaces. Note necrosis of all leaf tissue, epidermal cells (ep), palisade cells (ps), and spongy cells (sp). (F) Vertical section of lesion showing algal filaments (arrows) expanding subepidermally. (G) Vertical section of lesion showing algal filaments (arrows) expanding among cells of spongy tissue. (H) Transverse section of lesion showing development of thallus (arrows) beneath epidermal cells and formation of immature gametangia (ga) forming beneath cuticle. Necrosis of epidermal cells (ep), palisade

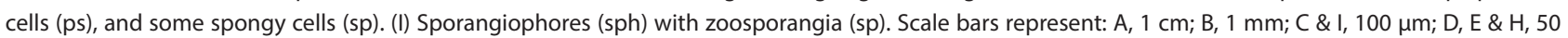
$\mu \mathrm{m} ; \mathrm{F} \& \mathrm{G}, 10 \mu \mathrm{m}$. 

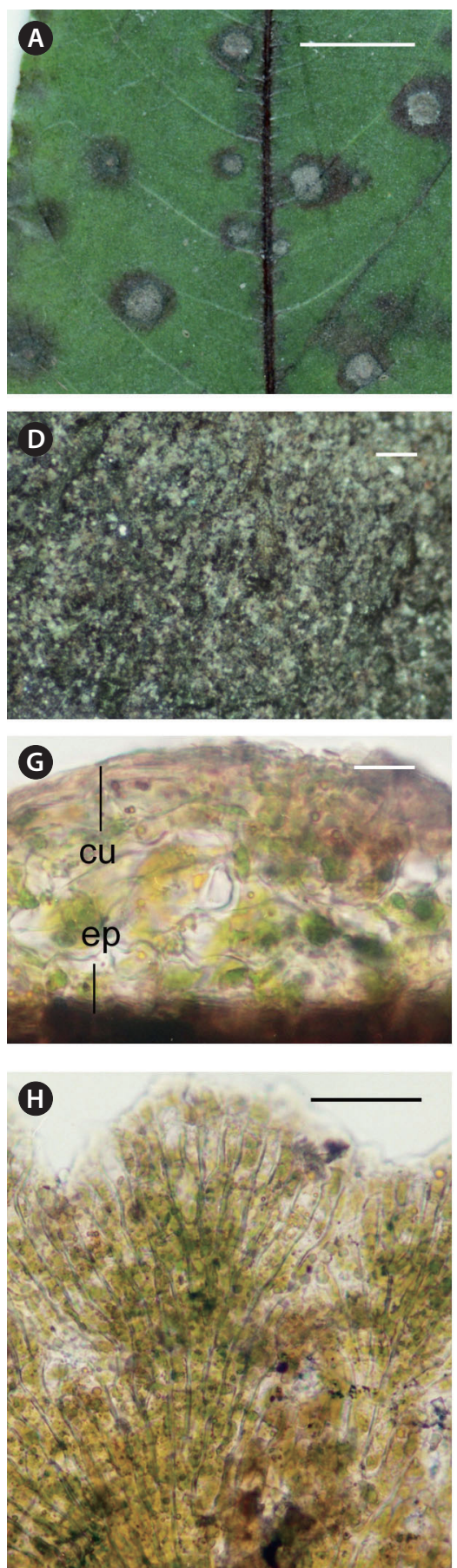
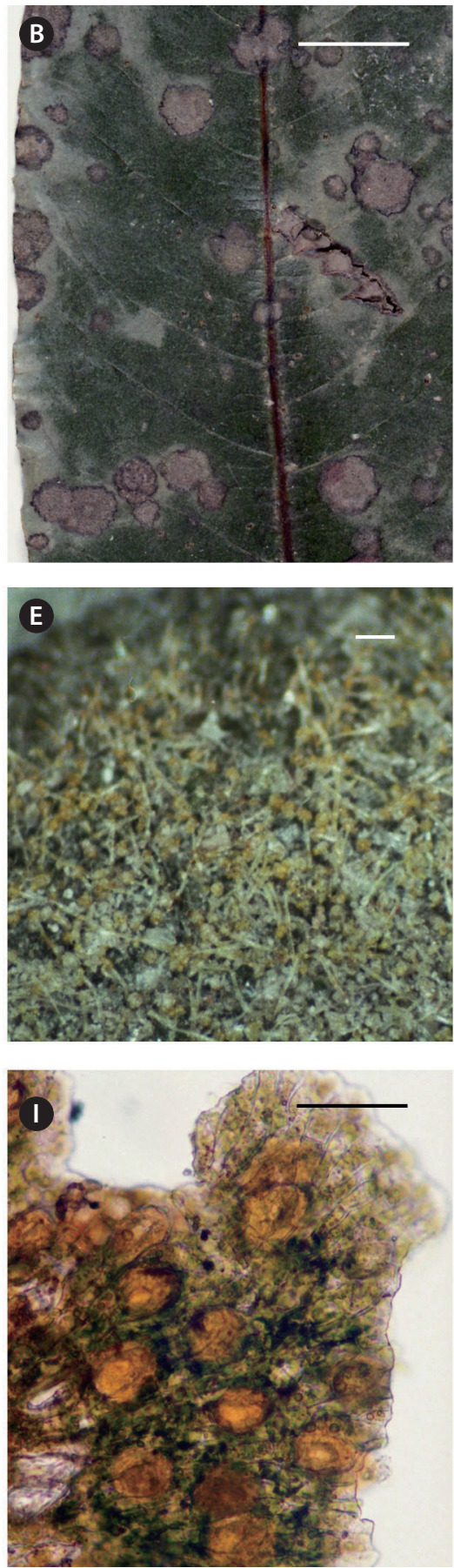
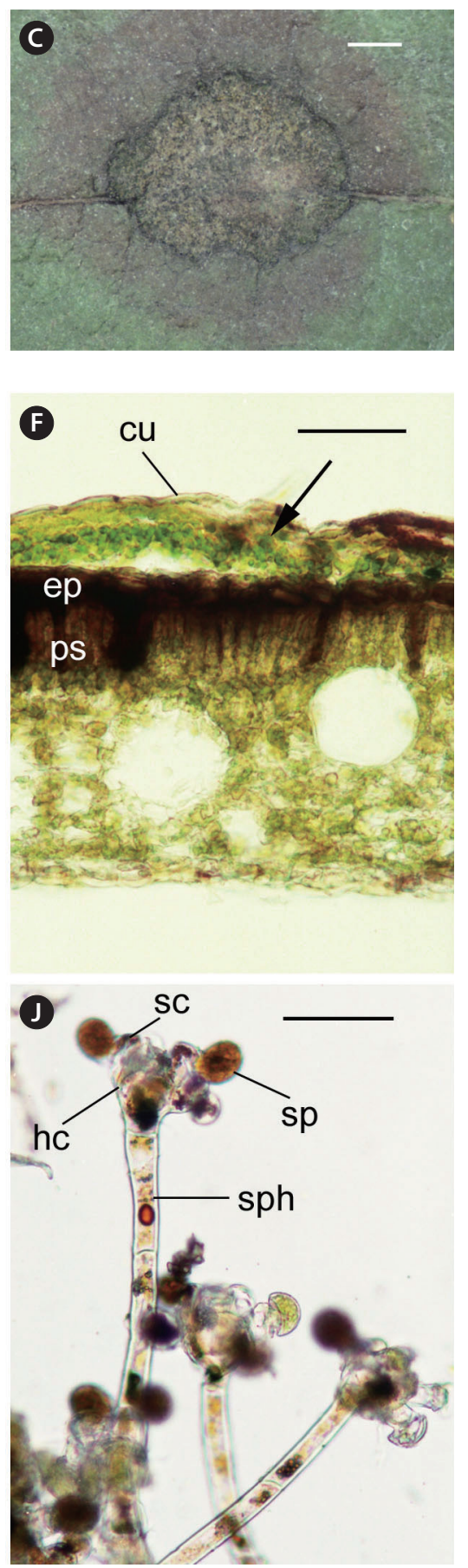

Fig. 2. Cephaleuros virescens in Polyalthia longifolia. (A) Thalli with purple stain on upper surface of young leaf. (B) Purple stain not visible on upper surface of old leaf. (C) Enlarged view of a circular disk. (D) Granules of gametangia aggregating. (E) Bush of sporangiophores with zoosporangia formed on thallus. (F) Transverse section of leaf showing development of thallus (arrow) beneath cuticle (cu) of upper leaf surface. Notice necrosis of epidermal cells (ep) and palisade cells (ps). (G) Algal filaments creeping between cuticle (cu) and epidermal cells (ep) of leaf. (H) Surface view of thallus showing pseudoparenchymatous ramuli with no gaps and crenate margin. (I) Surface view of gametangia produced from creeping filamentous cells. (J) Sporangiophore (sph), head cell (hc), suffultory cell (sc), and zoosporangium (sp). Scale bars represent: A \& B, $1 \mathrm{~cm} ; C, 1 \mathrm{~mm} ; D \& E, 100 \mu \mathrm{m} ; \mathrm{F} \& H-J, 50 \mu \mathrm{m} ; \mathrm{G}$, $10 \mu \mathrm{m}$. 
Table 1. Comparative features of Cephaleuros parasiticus and C. virescens

\begin{tabular}{cll}
\hline & \multicolumn{1}{c}{ Cephaleuros parasiticus } & \multicolumn{1}{c}{ Cephaleuros virescens } \\
\hline Macroscopic features & Lesion on both leaf surfaces & Thallus on upper leaf surface \\
& Zoosporangia on lower leaf surface & Zoosporangia on upper leaf surface \\
Microscopic features & Thallus subepidermal and intramatrical & Thallus subcuticular \\
& Necrosis of epidermis, palisade and spongy & Necrosis of epidermis and palisade tissue \\
& tissues and vascular bundles & \\
\hline
\end{tabular}

clearly different between C. parasiticus and C. virescens: 1) The spots are observed as lesions on both the leaf surfaces and no visible thalli are found in C. parasiticus, but only as thalli on the upper leaf surface in C. virescens. 2) The zoosporangia are formed on the lesion of the lower leaf surface in C. parasiticus, but on the thalli of the upper leaf surface in C. virescens. Microscopic features of the lesions and thalli. 3) The thalli grow subepidermally and intramatrically in C. parasiticus, but only subcuticularly in C. virescens. 4) Necrosis of the cells in host was found in the whole leaf tissue, but only epidermal and palisade cells in C. virescens. The two Cephaleuros species are easily divided and identified by the following macroscopic and microscopic features (Table 1).

Thompson and Wujek (1997) reported fusion of biflagellate gametes forming zygotes that grew into dwarf plants (= sporophytes) in Cephaleuros. These dwarf plants bore meiosporangia that produced quadriflagellate meiospores to complete the sexual cycle. Life-history studies on Cephaleuros are not well documented (Guiry and Guiry 2014). As in the case of 5 species of Cephaleuros from Japan (Suto and Ohtani 2013), we could not observe dwarf plants on the thalli of Indian Cephaleuros plants. Krishnamurthy (2000) contended that there is only one species (i.e., C. virescens) occurring in India and neighbouring countries. According to him, C. parasiticus is not distinct from $C$. virescens. Several earlier and recent authors Sarma 1986, Thompson and Wujek 1997, Ponmurugan et al. 2010, Ramya et al. 2013, Guiry and Guiry 2014) recognize both $C$. parasiticus and $C$. virescens as separate species. The present study also confirmed this last view point.

Evidently Syzygium aromaticum and Polyalthia longifolia are new host plants of C. parasiticus and C. virescens, respectively. The aesthetic value of these host trees is reduced by Cephaleuros infection. C. parasiticus is known to be a troublesome pathogen in some ornamental and crop plants, since the alga invades intramatrically (Thompson and Wujek 1997). However, the lesions are rather small and cause only slight damage in Syzygium aromaticum of our collection.

\section{REFERENCES}

Chowdary, Y. B. K. \& Jose, G. 1979. Biology of Cephaleuros Kunze in nature. Phykos 18:1-9.

Cunningham, D. D. 1897. On certain diseases of fungal and algal origin affecting economic plants in India. Sci. Mem. Med. Off. Army India 10:95-130.

Gokhale, M. V. \& Shaikh, S. S. 2012. Host range of a parasitic alga Cephaleuros virescens Kunz. ex Fri. from Maharashtra state, India. Plant Sci. Feed 2:1-4.

Guiry, M. D. \& Guiry, G. M. 2014. AlgaeBase. World-wide electronic publication, National University of Ireland, Galway. Available from: http://www.algaebase.org. Accessed Feb 22, 2014.

Krishnamurthy, V. 2000. Algae of India and neighbouring countries. I. Chlorophycota. Oxford \& IBH Publishing Co., New Delhi, 209 pp.

Mann, H. H. \& Hutchinson, C. M. 1904. Red rust; a serious blight of the tea plant. Indian Tea Assoc. Bull. 4:1-26.

Panikkar, W. V. N., Ampili, P. \& Chauhan, V. D. 1989. Observations on Cephaleuros virescens Kunze from Kerala, India. J. Econ. Taxon. Bot. 13:67-70.

Petch, T. 1923. The diseases of the tea Bush. MacMillan \& Co., London, $220 \mathrm{pp}$.

Ponmurugan, P., Saravanan, D. \& Ramya, M. 2010. Culture and biochemical analysis of a tea algal pathogen, Cephaleuros parasiticus. J. Phycol. 46:1017-1023.

Printz, H. 1939. Vorarbeiten zu einer Monographie der Trentepohliaceae. Nytt Mag. Naturvidensk. 80:137-210.

Ramya, M., Ponmurugan, P. \& Saravanan, D. 2013. Management of Cephaleuros parasiticus Karst. (Trentepholiales: Trentepohliaceae), an algal pathogen of tea plant, $\mathrm{Ca}$ mellia sinensis (L) (O. Kuntze). Crop Protection 44: 6674 .

Sarma, P. 1986. The freshwater Chaetophorales of New Zealand. Beih. Nova Hedwigia Beih. 58:1-169.

Saxena, P. N. 1961. Algae of India. 1. Chaetophorales. Bull. Natl. Bot. Gard. 57:1-59.

Suto, Y. \& Ohtani, S. 2009. Morphology and taxonomy of five Cephaleuros species (Trentepohliaceae, Chlorophyta) from Japan, including three new species. Phycologia 
48:213-236.

Suto, Y. \& Ohtani, S. 2013. Seasonal development of five Cephaleruos species (Trentepohliaceae, Chlorophyta) on the leaves of woody plants and the behaviors of their gametes and zoospores. Phycol. Res. 61:105-115.
Thompson, R. H. \& Wujek, D. E. 1997. Trentepohliales: Cephaleuros, Phycopeltis, and Stomatochroon: morphology, taxonomy, and ecology. Science Publishers Inc., Enfield, $\mathrm{NH}, 149$ pp. 